\title{
PENGARUH INTELEGENSI, TASK COMMITMENT DAN SELF EFFICACY TERHADAP HASIL BELAJAR MATEMATIKA SISWA SMA
}

\author{
Nur Qalbi Tayibu \\ Pendidikan Matematika Universitas Negeri Makassar \\ Email: ambhy_qalbhy@yahoo.com
}

\begin{abstract}
This study aims to determine the effect of intelligence, task commitment and self efficacy towards learning outcomes math class X SMA country Bulukumba District of Bulukumba. This type of research is ex-post facto nature of causality. The population in the study were students of Class X SMAN in District Bulukmpa Bulukumba 2014/2015 school year as many as 420 students and 201 students sample, taken by using proportional random sampling. The instrument used consisted of intelligence tests (tests of verbal linguistic intelligence, logical mathematical intelligence and visual-spatial), self-efficacy scale and the scale of task commitment and math achievement test. Data were analyzed using descriptive statistics and inferential statistics that path analysis (path anlysis). The research concludes that: (i) Most students of class X SMA in Bulukumba, have intelligence with the category average, task commitment in learning mathematics with high category, self-efficacy in mathematics with high category and yield learning mathematics are the very low category. (Ii) a variable that significantly that intelligence directly influence the outcome of learning mathematics, self-efficacy directly influence learning outcomes and task commitment directly influence the results of students' mathematics learning, intelligence indirect effect on the result of learning mathematics through task commitment and self-efficacy influential indirectly of mathematics learning outcomes through task commitment.
\end{abstract}

Keywords: intelligence, self-efficacy, task commitment, mathematics learning outcomes

\begin{abstract}
ABSTRAK
Penelitian ini bertujuan untuk mengetahui pengaruh intelegensi, task commitment dan self efficacy terhadap hasil belajar matematika siswa kelas X SMA negeri Kecamatan Bulukumpa Kabupaten Bulukumba. Jenis penelitian adalah ex-post facto yang bersifat kausalitas. Populasi dalam penelitian adalah siswa Kelas X SMA Negeri di Kecamatan Bulukmpa Kabupaten Bulukumba tahun ajaran 2014/2015 sebanyak 420 siswa dan Sampel 201 siswa, diambil dengan menggunakan proportional random sampling. Instrumen yang digunakan terdiri dari tes intelegensi (tes intelegensi verbal linguistik, intelegensi matematis logis dan visual spasial), skala self efficacy dan skala task commitment serta tes hasil belajar matematika. Data dianalisis dengan menggunakan statistika deskriptif dan statistika inferensial yakni analisis jalur (path anlysis). Hasil penelitian bahwa: (i) Sebagian besar siswa kelas X SMA Negeri di Kecamatan Bulukumpa Kabupaten Bulukumba, memiliki intelegensi dengan kategori rata-rata, task commitment dalam belajar matematika dengan kategori tinggi, self efficacy dalam belajar matematika dengan kategori tinggi dan hasil belajar matematika berada pada kategori sangat rendah. (ii) variabel yang berpengaruh secara signifikan yaitu intelegensi berpengaruh langsung terhadap hasil belajar matematika, self efficacy berpengaruh langsung terhadap hasil belajar serta task commitment berpengaruh langsung terhadap hasil belajar matematika siswa, intelegensi berpengaruh tidak langsung terhadap hasil belajar matematika melalui task commitment dan self efficacy berpengaruh tidak langsung terhadap hasil belajar matematika melalui task commitment.
\end{abstract}

Kata kunci: intelegensi, self efficacy, task commitment, hasil belajar matematika 


\section{PENDAHULUAN}

Matematika sebagai ilmu dasar dari segala bidang ilmu pengetahuan merupakan hal yang sangat penting untuk kita ketahui. Oleh sebab itu, matematika perlu diajarkan di semua jenjang pendidikan formal, mulai dari sekolah dasar sampai perguruan tinggi.

Pentingnya matematika bisa dilihat dari manfaat dan kegunaan matematika dalam kehidupan sehari-hari, juga bagi perkembangan ilmu pengetahuan. Oleh karena itu penyempurnaan kurikulum terus dilakukan oleh Departemen Pendidikan Nasional.

Pentingnya matematika tidak dibarengi dengan peningkatan hasil belajar dalam bidang ini. Pada kenyataannya hasil belajar matematika yang diperoleh siswa kelas X SMA Negeri 2 Bulukumba dan SMA Negeri 14 Bulukumba, tercatat bahwa hasil ujian semester ganjil tahun ajaran 2014/ 2015, 4 dari 9 kelas memperoleh nilai rata-rata 76 untuk SMA Negeri 1 Bulukumba sedangkan pada SMA Negeri 14 Bulukumba memperoleh nilai rata-rata ujian semester ganjil yaitu 74 untuk 1 dari 3 kelas di SMA tersebut.

Rendahnya hasil belajar matematika siswa, dipengaruhi oleh banyak faktor. Salah satu faktor penyebabnya adalah dari dalam diri siswa yaitu mengalami masalah dalam mempelajari matematika. Selain itu bisa juga karena faktor lingkungan yang tidak mendukung siswa untuk belajar matematika secara maksimal. Menurut Sardiman (2011: 45), secara garis besar faktorfaktor yang mempengaruhi hasil belajar dapat diklasifikasikan menjadi dua, yaitu: (1) faktor internal, yakni faktor yang berasal dari dalam diri individu, yang meliputi faktor fisiologis seperti penglihatan dan pendengaran dan faktor psikologis seperti perhatian, pengamatan, tanggapan, fantasi, ingatan, berpikir, bakat dan motivasi, dan (2) faktor eksternal, yakni faktor yang berasal dari luar diri individu, yang meliputi faktor sosial dan faktor non sosial.

Banyak orang yang berpendapat bahwa untuk meraih hasil belajar yang tinggi, seseorang harus memiliki intelegensi yang tinggi, karena inteligensi merupakan bekal potensial yang akan memudahkan dalam belajar dan pada gilirannya akan menghasilkan hasil belajar yang lebih baik. Menurut Suryabrata (2014: 121), inteligensi merupakan salah satu faktor penting yang ikut menentukan berhasil atau gagalnya belajar seseorang. Hal serupa ditambahkan juga oleh Syah (2011: 131) bahwa tingkat intelegensi atau kecerdasan siswa tak dapat diragukan lagi sangat menentukan tingkat keberhasilan belajar siswa.

Terkadang banyak anak-anak yang mempunyai IQ tinggi mempunyai hasil belajar dibawah anak-anak yang memiliki IQ rata-rata. Memang keberhasilan belajar seseorang sangat ditentukan antara lain oleh kemampuan kognitif, tetapi ternyata bahwa faktor non kognitif tidak kalah penting bahkan mempengaruhi perkembangan seseorang. Banyak anak-anak yang sebenarnya berpotensi untuk mempunyai hasil belajar yang baik, namun justru memiliki hasil belajar rendah, karena beberapa faktor yang mendukung untuk berhasil belajar, tidak dimilikinya seperti task commitment.

Komitmen terhadap tugas (task commitment) menurut Renzulli (Syarifah dkk, 2011: 2) merupakan suatu bentuk halus dari motivasi. Jika motivasi biasanya didefinisikan sebagai suatu proses energi umum yang merupakan faktor pemicu pada organisme, tanggung jawab energi tersebut ditampilkan pada tugas tertentu yang spesifik.

Menurut Hawadi (Firmanto, 2013: 27), rendahnya keterikatan terhadap tugas dapat memunculkan kesenjangan antara potensi yang dimilikinya dengan prestasi yang ditunjukkannya. Hal ini juga didukung oleh Urhahne (Firmanto, 2013: 28), siswa yang memiliki task commitment tinggi menunjukkan perilaku yang positif terhadap semua tugastugasnya sebagai pelajar. Menurut Hawadi (2002) berkurangnya komitmen anak terhadap tugas akan berakibat berkurang pula kesempatan bagi guru untuk mengembangkan potensi

Sukses tidaknya seorang siswa di sekolah sangat dipengaruhi oleh semangat yang tinggi, rasa optimis yang besar dan motif untuk sukses yang tinggi pula sehingga diharapkan siswa dapat sukses dalam menjalani kehidupan selanjutnya dan mempunyai hasil belajar yang optimal. Oleh karena itu, setiap siswa diharapkan memiliki self efficacy yang merupakan kemampuan untuk menyusun tindakan yang dibutuhkan dalam menyelesaikan tugas-tugas khusus yang dihadapi. Sel efficacy lebih spesifik pada tugas atau situasi dan hanya melibatkan penilaian (bukan perasaan). 
Menurut Bandura (Ormrod, 2009: 21), perasaan self efficacy siswa mempengaruhi pilihan aktivitas mereka, tujuan mereka dan usaha serta persistensi mereka dalam saktivitasaktivitas di kelas. Dengan demikian self efficacy pun pada akhirnya mempengaruhi pembelajaran dan prestasi mereka.

Inti dari persoalan hakekat intelegensi itu dapat di rumuskan dengan pertanyaan: "Apakah intelegensi itu?". Pertanyaan itu justru dalam bentuknya yang demikian menjadi objek diskusi yang hangat bagi banyak ahli-ahli psikologi, terutama disekitar tahun 1900-1925.

Menurut Reber (Syah, 2011: 131) bahwa intelegensi pada umumnya dapat diartikan sebagai kemampuan psiko-fisik untuk mereaksi rangsangan atau menyesuaikan diri dengan lingkungan dengan cara yang tepat.

Sedangkan menurut Geary (Suryabrata, 2014: 122) menyatakan bahwa intelegensi dalam hal perbedaan individu dalam bereaksi terhadap waktu, waktu "inspeksi" (inspection time), dan kerja memori secara de facto diukur melalui tes intelegensi standar.

Alfret Binet (Azwar, 2013: 5), seorang tokoh utama perintis pengukuran intelegensi bersama Theodore Simon mendefinisikan intelegensi sebagai suatu hal yang terdiri dari tiga komponen, yaitu:

a. Kemampuan untuk mengarahkan fikiran atau mengarahkan tindakan.

b. Kemampuan untuk mengubah arah tindakan bila tindakan tersebut telah dilaksanakan

c. Kemampuan untuk mengkritik diri sendiri atau melakukan autocrticism.

Dari beberapa pendapat para ahli mengenai intelegensi di atas, maka dapat ditarik suatu kesimpulan bahwa hakekat intelegensi adalah kemampuan seseorang untuk mengambil tindakan dan menyesuaikan tindakan guna untuk mencapai suatu tujuan tertentu.

Menurut Hawadi (Firmanto, 2013: 27), komitmen terhadap tugas (task commitment) secara awam dapat dipahami sebagai motivasi dari dalam diri atau motivasi internal yang dapat menjadi daya dorong amat kuat untuk memunculkan potensi yang dimiliki. Rendahnya keterikatan terhadap tugas dapat memunculkan kesenjangan antara potensi yang dimilikinya dengan hasil yang ditunjukkannya. Menurut Renzulli (Syarifah dkk, 2011: 2) bahwa task commitment merupakan bentuk halus dari motivasi.
Menurut Hawadi (2002) berkurangnya task commitment anak akan berakibat berkurang pula kesempatan bagi guru untuk mengembangkan potensi anak. Karena task commitment merupakan motivasi internal yang dapat menjadi daya dorong amat kuat untuk memunculkan potensi yang dimiliki.

Apabila seseorang tidak berhasil menggunakan cara pertama karena terhalang oleh berbagai hambatan maka ia akan mencoba cara kedua dan seterusnya hingga ia berhasil menemukan cara yang tepat untuk mencapai tujuannya yang diharapkan atau untuk menjalankan dengan sungguh-sungguh tugas yang diberikan kepadanya. Disinilah task commitment pada diri seseorang terlihat.

Dari beberapa pengertian tentang task commitment diatas, Hawadi (Winarti, 2006: 26) membatasi pengertian task commitment pada lima dimensi yaitu:

1. Tangguh ulet, dan tidak mudah bosan

2. Mandiri

3. Menetapkan tujuan aspirasi yang realistis dengan resiko sedang

4. Suka belajar dan mempunyai hasrat untuk meningkatkan diri

5. Mempunyai hasrat untuk berhasil dalam bidang akademis.

Dari uraian diatas dapat ditarik kesimpulan bahwa task commitment berarti suatu tekad yang kuat dalam diri sendiri, yang tak memerlukan dorongan dari luar untuk mencapai suatu hasil yang ditunjukkan dengan sikap-sikap. Perilaku aktual dari task commitment adalah sebagai bentuk ketekunan, keuletan kerja keras, latihan yang terus-menerus, percaya diri dan suatu keyakinan dari kemampuan seseorang untuk menyelesaikan pekerjaan penting. Sedang task (tugas) yang dimaksudkan dalam penelitian ini adalah tugas siswa dalam belajar, jadi commitment yang dimaksudkan disini dispesifikasikan pada tugas-tugas sekolah.

Menurut Bandura (Ghufron \& Risnawita, 2010), ia mendefenisikan bahwa self efficacy adalah keyakinan individu mengenai kemampuan dirinya dalam melakukan tugas atau tindakan yang diperlukan untuk mencapai hasil tertentu. Dia pun mengatakan bahwa self efficacy pada dasarnya adalah hasil dari proses kognitif berupa keputusan, keyakinan atau pengharapan tentang sejauh mana individu memperkirakan kemampuan dirinya dalam melaksanakan tugas 
atau tindakan tertentu yang diperlukan untuk mencapai hasil yang diinginkan.

Menurut Ormrod (2009: 20) bahwa secara umum self efficacy adalah penilaian seorang tentang kemampuannya sendiri untuk menjalankan perilaku tertentu atau mencapai tujuan tertentu. Self efficacy bersifat lebih spesifik pada tugas atau situasi dan hanya melibatkan penilaian bukan dengan perasaan.

Dari paparan mengenai self efficacy, maka dapat ditarik suatu kesimpulan bahwa self efficacy merupakan penilaian seseorang mengenai sejauh mana kemampuannya untuk mencapai tujuan tertentu.

Self efficacy dapat dibagi menjadi 3 dimensi yaitu dimensi tingkat (level), kekuatan (strength), dan generalisasi (generality).

Hasil belajar adalah pola-pola perbuatan, nilai-nilai, pengertian-pengertian, sikap-sikap, apresiasi dan keterampilan. Menurut Nana Sudjana (Kunandar, 2008: 276) hasil belajar adalah suatu akibat dari proses belajar dengan menggunakan alat pengukuran, yaitu berupa tes yang disusun secara terencana, baik tes tertulis, tes lisan, maupun tes perbuatan.

Sedangkan menurut Nasution (Kunandar, 2008: 276) bahwa hasil belajar adalah suatu perubahan pada individu yang belajar, tidak hanya mengetahui pengetahuan, tetapi juga membentuk kecakapan dan penghayatan dalam diri pribadi individu yang belajar.

Jadi, hasil belajar matematika merupakan suatu ukuran berhasil atau tidaknya seseorang siswa dalam proses belajar matematika dengan memahami arti hubungan symbol-simbol, kemudian menerapkan konsep tersebut dalam dunia nyata. Dalam penelitian ini, yang dimaksud hasil belajar siswa adalah hasil nilai tes siswa yang diberikan menggunakan tes hasil belajar.

Berdasarkan pemaparan di atas, maka dapat diasumsikan bahwa intelelegensi, task commitment dan self efficacy merupakan tiga variabel yang dapat mempengaruhi hasil belajar matematika siswa. Dengan demikian dapat disimpulkan bahwa faktor-faktor yang bisa berpengaruh terhadap rendahnya hasil belajar matematika siswa adalah intelegensi, task commitment dan self efficacy. Oleh karena itu penulis tertarik untuk melakukan penelitian mengenai pengaruh intelegensi, task commitment dan self efficacy terhadap hasil belajar matematika siswa.
Berdasarkan latar belakang yang telah dipaparkan di atas, maka dapat dirumuskan pertanyaan-pertanyaan penelitian yaitu: (1) Bagaimana gambaran intelegensi, task commitment, self efficacy dan hasil belajar matematika siswa kelas X SMA Negeri di Kecamatan Bulukumpa? (2) Apakah intelegensi berpengaruh positif baik secara langsung maupun tidak langsung melalui task commitment terhadap hasil belajar matematika siswa kelas $\mathrm{X}$ SMA Negeri di Kecamatan Bulukumpa?. (3) Apakah self efficacy berpengaruh positif baik secara langsung maupun tidak langsung melalui task commitment terhadap hasil belajar matematika siswa kelas X SMA Negeri di Kecamatan Bulukumpa?. (4) Apakah task commitment berpengaruh positif pada hasil belajar matematika siswa kelas X SMA Negeri di Kecamatan Bulukumpa?. (

Adapun hipotesis dalam penelitian adalah sebagai berikut: (1) Intelegensi berpengaruh positif baik secara langsung maupun tidak langsung melalui task commitment terhadap hasil belajar matematika siswa kelas X SMA Negeri di Kecamatan Bulukumpa. (2) Self efficacy berpengaruh positif baik secara langsung maupun tidak langsung melalui task commitment terhadap hasil belajar matematika siswa kelas X SMA Negeri di Kecamatan Bulukumpa. (3) Task commitment siswa berpengaruh positif terhadap hasil belajar matematika siswa siswa kelas $\mathrm{X}$ SMA Negeri di Kecamatan Bulukumpa.

\section{METODE PENELITIAN}

Jenis penelitian ini termasuk penelitian expost facto yang bersifat kausalitas. Peneliti dalam hal ini akan menelusuri hubungan sebab akibat dan menguji hipotesis yang telah dirumuskan sebelumnya antara intelegensi, task commitment dan self efficacy.

Variabel yang terdapat dalam penelitian ini terdiri atas 3 jenis variabel yaitu terdiri dari variabel eksogen, variabel intervening dan variabel endogen. Variabel eksogen yaitu intelegensi dan self efficacy, variabel intervening yaitu task commitment dan variabel endogen yaitu hasil belajar matematika.

Populasi dalam penelitian ini adalah seluruh siswa kelas X SMA Negeri di Kecamatan Bulukumpa sebanyak 2 sekolah yaitu SMA Negeri 2 Bulukumpa dan SMA Negeri 14 Bulukumba dengan jumlah keseluruhan siswa 
dari kedua sekolah khususnya kelas $\mathrm{X}$ adalah 420 siswa. Metode pengambilan sampel dalam penelitian ini adalah menggunakan teknik Proporsionate Random Sampling. Penentuan besar sampel dilakukan dengan menghendaki tingkat kepercayaan $95 \%$ dari jumlah populasi sebanyak 420 siswa, maka banyaknya siswa yang menjadi subjek penelitian ini ditentukan berdasarkan tabel yang dipublikasikan oleh Yamane (Tiro \& Arbianingsih, 2011: 120) sebanyak 138 siswa dengan tingkat ketepatan $7 \%$. Kemudian ditambahkan sebanyak $15 \%$ untuk sampel yang diluar jangkauan. Sehingga total sampel dalam penelitian ini sebanyak 201 siswa dengan rincian 4 kelas di SMA Negeri 2 Bulukumba dan 2 kelas di SMA Negeri 14 Bulukumba.

Instrumen yang digunakan dala penelitian ini berupa tes dan skala. Tes digunakan untuk mengukur intelegensi; dimana tes intelegensi berupa tes intelegensi verbal linguistic, matematis logis, visual spasial, dan hasil belajar matematika. Sedangkan skala digunakan umtuk mengukur self efficacy dan task commitment belajar siswa. Pada penelitian ini akan digunakan Skala Likert dengan memodifikasi menghilangkan jawaban tengah atau dengan jawaban skala Likert 5-titik. Skala Likert 5-titik diambil sebagai patokan pada semua butir pernyataan dalam skala penilaian. Oleh karena itu, dalam Skala Likert 5-titik, alasan responden akan diberikan pernyataan dengan pilihan penilaian diri responden antara interval 1 sampai 5. Angka 1 sampai 5 ini merupakan skor nilai dari penilaian responden yang memiliki arti. Skala self efficacy dan task commitment untuk pernyataan positif skor 5 bila responden menjawab sangat sesuai (SS), skor 4 bila responden menjawab sesuai (S), skor 3 bila responden menjawab netral $(\mathrm{N})$ skor 2 bila responden menjawab tidak sesuai (TS), dan skor 1 bila responden menjawab sangat tidak sesuai (STS). Pernyataan negatif skor 1 bila responden menjawab sangat sesuai (SS), skor 2 bila responden menjawab sesuai (S), skor 3 jika responden menjawab Netral (N), skor 4 jika responden menjawab tidak sesuai (TS) dan skor 5 jika responden menjawab sangat tidak sesuai (STS).

Adapun analisis butir yang dilakukan setelah pelaksanaan uji coba instrumen menurut Tiro \& Sukarna (2012: 134) adalah sebagai berikut:

a. Uji kekonsistenan internal (internal consistency) setiap item/butir yang dilakukan dengan cara analisis korelasi antara skor butir dan skor total.

b. Uji validitas/kesahihan konstrak (construct validity) yang dilakukan dengan cara analisis faktor konfirmasi (confirmatory factor analysis) berdasarkan kisi-kisi instrumen.

c. Menghitung koefisien reliabilitas (keandalan). Keandalan (reliability) memberikan informasi mengenai kekonsistenan instrumen dalam memberikan skor pada responden, dalam artian responden yang memperoleh skor tinggi atau rendah sesuai dengan kondisi atau keadaannya.

Teknik analisis data yang digunakan adalah analisis statistik deskriptif yang terdiri dari mean, standar deviasi, nilai maksimum, nilai minimum, variansi, skewness, kurtosis, dan tabel distribusi frekuensi. Selain analisis deskriptif, analisis yang digunakan juga adalah analisis analisis jalur (analysis path).

\section{HASIL PENELITIAN}

\section{Hasil}

Tabel 1.1 Distribusi Intelegensi

\begin{tabular}{ccccl}
\hline No. & Skor & Frekuensi & Persentase (\%) & \multicolumn{1}{c}{ Kategori } \\
\hline $\mathbf{1}$ & $\geq 130$ & - & - & Gifted \\
$\mathbf{2}$ & $120-129$ & - & - & Superior \\
$\mathbf{3}$ & $110-119$ & 47 & 23 & Bright Normal \\
$\mathbf{4}$ & $90-109$ & 114 & 57 & Average \\
$\mathbf{5}$ & $80-89$ & 33 & 16 & Dull Normal \\
$\mathbf{6}$ & $70-79$ & 6 & 3 & Borderline \\
$\mathbf{7}$ & $\leq 69$ & 1 & 1 & Defective \\
\hline & Jumlah & $\mathbf{2 0 1}$ & & \\
\hline
\end{tabular}


Tabel 1.2. Gambaran Deskriptif Intelegensi

\begin{tabular}{cc}
\hline & Statistik Deskriptif \\
\hline Mean & 100,03 \\
Std. Deviasi & 11,16 \\
Variansi & 124,56 \\
Minimum & 69 \\
Maksimum & 119 \\
Taksiran Rata-Rata & $98,40 \leq \mu \leq 101,66$ \\
\hline
\end{tabular}

Tabel 1.3 Distribusi Skor Self Efficacy

\begin{tabular}{ccccc}
\hline No. & Skor & Frekuensi & Persentase (\%) & Kategori \\
\hline $\mathbf{1}$ & $66 \leq \mathrm{SE} \leq 76$ & 13 & 6 & Sangat Tinggi \\
$\mathbf{2}$ & $57 \leq \mathrm{SE} \leq 65$ & 75 & 37 & Tinggi \\
$\mathbf{3}$ & $48 \leq \mathrm{SE} \leq 56$ & 69 & 34 & Sedang \\
$\mathbf{4}$ & $39 \leq \mathrm{SE} \leq 47$ & 28 & 14 & Rendah \\
$\mathbf{5}$ & $30 \leq \mathrm{SE} \leq 38$ & 16 & 8 & Sangat Rendah \\
\hline & Jumlah & $\mathbf{2 0 1}$ & $\mathbf{1 0 0}$ & \\
\hline
\end{tabular}

Tabel 1.4. Gambaran Deskriptif Skala Self Efficacy

\begin{tabular}{cc}
\hline & Statistik Deskriptif \\
\hline Mean & 54,30 \\
Std. Deviasi & 9,21 \\
Variansi & 84,83 \\
Minimum & 30 \\
Maksimum & 76 \\
Taksiran Rata-Rata & $52,96 \leq \mu \leq 55,64$ \\
\hline
\end{tabular}

Tabel 1.5 Distribusi Skor Task Commitment

\begin{tabular}{ccccc}
\hline No. & Skor & Frekuensi & Persentase (\%) & Kategori \\
\hline $\mathbf{1}$ & $85 \leq \mathrm{TC} \leq 99$ & 48 & 24 & Sangat Tinggi \\
$\mathbf{2}$ & $70 \leq \mathrm{TC} \leq 85$ & 97 & 48 & Tinggi \\
$\mathbf{3}$ & $55 \leq \mathrm{TC} \leq 69$ & 45 & 22 & Sedang \\
$\mathbf{4}$ & $40 \leq \mathrm{TC} \leq 54$ & 10 & 5 & Rendah \\
$\mathbf{5}$ & $25 \leq \mathrm{TC} \leq 39$ & 1 & 1 & Sangat Rendah \\
\hline & Jumlah & $\mathbf{2 0 1}$ & $\mathbf{1 0 0}$ & \\
\hline
\end{tabular}

Tabel 1.6 Gambaran Deskriptif Skala Task Commitment

\begin{tabular}{cc}
\hline & Statistik Deskriptif \\
\hline Mean & 75,35 \\
Std. Deviasi & 12,69 \\
Variansi & 161,03 \\
Minimum & 25 \\
Maksimum & 99 \\
Taksiran Rata-Rata & $73,52 \leq \mu \leq 77,18$ \\
\hline
\end{tabular}


Tabel 1.7 Distribusi Hasil Belajar Matematika

\begin{tabular}{|c|c|c|c|c|}
\hline No. & Skor & Frekuensi & Persentase (\%) & Kategori \\
\hline 1 & $90 \leq \mathrm{THB} \leq 100$ & 1 & 1 & Sangat Tinggi \\
\hline 2 & $80 \leq \mathrm{THB}<89$ & 32 & 16 & Tinggi \\
\hline 3 & $65 \leq \mathrm{THB}<79$ & 57 & 28 & Sedang \\
\hline 4 & $55 \leq \mathrm{THB}<64$ & 3 & 2 & Rendah \\
\hline 5 & $0 \leq \mathrm{THB}<54$ & 108 & 55 & Sangat Rendah \\
\hline & Jumlah & 201 & 100 & \\
\hline
\end{tabular}

Tabel 1.8 Gambaran Deskriptif Tes Hasil Belajar Matematika

\begin{tabular}{cc}
\hline & Statistik Deskriptif \\
\hline Mean & 50,95 \\
Std. Deviasi & 21,70 \\
Variansi & 470,96 \\
Minimum & 6,70 \\
Maksimum & 93,3 \\
Taksiran Rata-Rata & $47,80 \leq \mu \leq 54,10$ \\
\hline
\end{tabular}

Hasil dari analisis jalur dapat dilihat pada Lampiran 8 dan secara sederhana dapat dilihat pada Gambar 1.1 berikut:

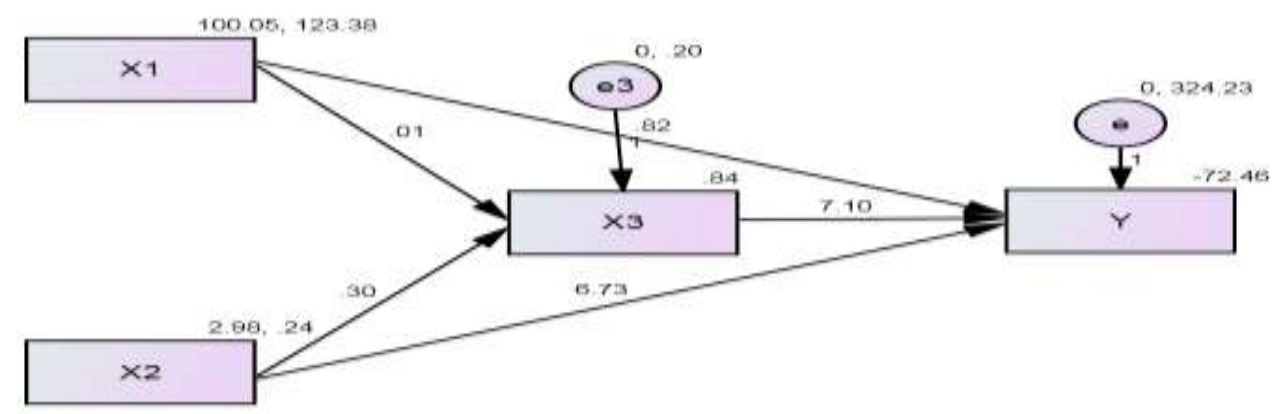

Gambar 1.1.Diagram Hasil Analisis Jalur Amos

Tabel 1.9 Regression Weights

\begin{tabular}{llllllr}
\hline & & & Estimate & S.E. & C.R. & \multicolumn{1}{c}{ P } \\
\hline X3 & $<---$ & X1 & 0,013 & 0,003 & 4,463 & $<0,001$ \\
X3 & $<---$ & X2 & 0,300 & 0,065 & 4,603 & $<0,001$ \\
Y & $<---$ & X3 & 7,103 & 2,875 & 2,470 & 0,013 \\
Y & $<---$ & X1 & 0,820 & 0,122 & 6,741 & $<0,001$ \\
Y & $<---$ & X2 & 6,731 & 2,783 & 2,418 & 0,016 \\
\hline
\end{tabular}


Tayibu. Pengaruh intelegensi, task...139

Tabel 1.10 Standardized Regression Weights

\begin{tabular}{lllr}
\hline & & & Estimate \\
\hline X3 & $<---$ & X1 & 0,290 \\
X3 & $<---$ & X2 & 0,299 \\
Y & $<---$ & X3 & 0,162 \\
Y & $<---$ & X1 & 0,427 \\
Y & $<---$ & X2 & 0,154 \\
\hline
\end{tabular}

Koefisien jalur yang tertera pada Gambar 1.1 bukanlah yang terbakukan (unstandardized) sehingga untuk membandingkan antara koefisien yang satu dengan yang lainnya digunakan koefisien terbakukan (standardized coefficient) (Tiro, Sukarna \& Aswi, 2010:63). Berdasarkan Lampiran 8 dapat disajikan koefisien jalur terbakukan yang dapat dilihat pada Lampiran 8 (standardized regression), maka dapat dibuat persamaan struktur sebagai berikut:

Persamaan Struktur 1: $\mathrm{X}_{3}=\mathrm{Px}_{3} \mathrm{X}_{1} \mathrm{X}_{1}+\mathrm{Px}_{3} \mathrm{X}_{2} \mathrm{X}_{2}$ $+\mathrm{Px}_{3} \varepsilon_{3}$

$$
\mathrm{X}_{2}+\varepsilon_{3} \quad=0,290 \mathrm{X}_{1}+0,299
$$

Persamaan Struktur 2: $\mathrm{Y}=\mathrm{Pyx}_{1} \mathrm{X}_{1}+\mathrm{Pyx}_{2} \mathrm{X}_{2}+$ $\mathrm{Pyx}_{3} \mathrm{X}_{3}+\mathrm{P}_{\mathrm{Y} \varepsilon}$

$$
=0,427 \mathrm{X}_{1}+0,154
$$

$X_{2}+0,162 X_{3}+\varepsilon$

Untuk melihat seberapa besar pengaruh langsung, pengaruh tidak langsung dan pengaruh total dapat dilihat pada Lampiran 8 yang disederhanakan pada Tabel 1.11 yang merupakan Tabel Dekomposisi Kausalitas

\begin{tabular}{|c|c|c|c|c|}
\hline No. & Pengaruh Peubah & $\mathbf{L}$ & TL & Total \\
\hline 1 & $\begin{array}{lll}\mathrm{X}_{1} & \mathrm{Ke} & \mathrm{X}_{3}\end{array}$ & 0,290 & - & 0,290 \\
\hline 2 & $X_{2} \quad \mathrm{Ke} \quad X_{3}$ & 0,299 & - & 0,299 \\
\hline 3 & $\mathrm{X}_{3} \mathrm{Ke} \quad \mathrm{Y}$ & 0,162 & - & 0,162 \\
\hline 4 & $\underset{\text { melalui } X_{3}}{X_{1}} \operatorname{Ke}$ & 0,427 & 0,047 & 0,474 \\
\hline 5 & $\underset{\text { melalui } \mathrm{X}_{3}}{\mathrm{X}_{2}} \mathrm{Ke}$ & 0,154 & 0,046 & 0,200 \\
\hline
\end{tabular}
Koefisien Jalur.

Tabel 1.11. Dekomposisi dari Koefisien Jalur

\section{Pembahasan}

1. Intelegensi Berpengaruh Positif terhadap Hasil Belajar Matematika Baik Secara Langsung Maupun Tidak Langsung Melalui Task Commitment

Hipotesis pertama dalam penelitian ini adalah intelegensi berpengaruh positif terhadap hasil belajar matematika baik secara langsung maupun tidak langsung melalui task commitment siswa. Berdasarkan hasil pengujian, maka dapat diketahui bahwa hipotesis pertama diterima sebab variabel intelegensi berpengaruh langsung maupun tidak langsung melalui task commitment terhadap hasil belajar matematika.

Terkait dengan pembahasan di atas, maka intelegensi berpengaruh terhadap hasil belajar matematika siswa. Hal ini diperkuat oleh Hadis \& Nurhayati (2014: 49) bahwa "intelegensi merupakan faktor psikologis yang turut mempengaruhi keberhasilan proses dan hasil pendidikan di sekolah". Hal senada dinyatakan oleh Syah (2011: 131) bahwa "tingkat intelegensi atau kecerdasan siswa tak dapat diragukan lagi sangat menentukan tingkat keberhasilan belajar siswa". Lebih lanjut Gardner (Sudiarta dkk, 2013: 2) menambahkan bahwa "siswa yang 
memiliki dan mengembangkan kecerdasan linguistik dan logis-matematis dijamin pasti akan berhasil dalam situasi sekolah tradisional".

Hal ini diperkuat oleh penelitian yang dilakukan M. Jainuri (2009), temuan penelitiannya menerangkan bahwa faktor intelegensi sangat mempengaruhi siswa dalam pencapaian prestasi belajarnya. selain itu, Omar M. Muammar (2011) meneliti mengenai inteligensi dan pengendalian diri. Hasil penelitiannya menunjukkan bahwa inteligensi berkorelasi secara signifikan dengan prestasi akademik.

Berbicara mengenai pengaruh tidak langsung intelegensi terhadap hasil belajar matematika siswa melalui task commitment, diperoleh pengaruh positif. Task commitment merupakan bentuk halus dari motivasi. Komitmen terhadap tugas (task commitment) menurut Renzulli (Syarifah dkk, 2011) merupakan suatu bentuk halus dari motivasi. Motivasi yang terlibat hanya dalam suatu kegiatan terutama untuk kepentingan diri sendiri disebut dengan motivasi intrinsik. Ketika seseorang merasa, baik penentuan diri maupun kompetensinya dalam mengerjakan tugas, motivasi intrinsik muncul dan mengarah pada suatu tindakan sehingga dapat dikatakan bahwa task commitment merupakan perwujudan dari motivasi intrinsik.

Menurut Razali dkk (Setyaningsih, 2009: 13), bahwa salah satu faktor yang mempengaruhi task commitment adalah intelegensi. Inteligensi yang tinggi, juga cenderung mempengaruhi seseorang untuk bertanggung jawab dan menjaga komitmennya terhadap tugas yang dikerjakannya sehingga berdampak pada proses belajarnya. Hal ini diperkuat oleh pemelitian yang dilakukan Firmanto (2013), hasil penelitiannya menunjukkan variabel kecerdasan, kreativitas dan task commitment merupakan variabel yang memiliki kontribusi kuat terhadap prestasi hasil belajar.

2. Self Efficacy Berpengaruh Positif terhadap Hasil Belajar Matematika Baik Secara Langsung Maupun Tidak Langsung Melalui Task Commitment

Hipotesis kedua dalam penelitian ini adalah self efficacy berpengaruh positif terhadap hasil belajar matematika baik secara langsung maupun tidak langsung melalui task commitment siswa. Berdasarkan hasil pengujian, maka dapat diketahui bahwa hipotesis kedua diterima sebab variabel self efficacy berpengaruh langsung maupun tidak langsung melalui task commitment terhadap hasil belajar matematika.

Dari hasil penelitian ini menggambarkan bahwa self efficacy merupakan faktor penting dalam pencapaian prestasi belajar siswa yang memiliki kemampuan dan kepribadian yang utuh. Hal ini pun diperkuat oleh penelitian yang dilakukan Stajkovic \& Luthans (Harahap, 2011) mengemukakan bahwa orang yang memiliki self efficacy yang tinggi akan mampu meraih cita-cita dengan baik, kerja lebih maksimal dibandingkan dengan orang yang rendah self efficacy-nya. Hal ini tidak tergantung pada jenis keterampilan atau keahlian siswa tetapi berhubungan dengan keyakinan tentang apa yang dapat dilakukan, dan menyangkut seberapa besar usaha yang dikeluarkan dalam suatu tugas (task commitment) dan seberapa lama ia bertahan dalam mencapai tujuan. Penelitian lain juga ditunjukkan oleh Pongsitammu (2014) bahwa terdapat pengaruh positif dan signifikan efikasi diri terhadap hasil belajar matematika siswa kelas VII SMP Negeri 1 Tondano.

Mengenai self efficacy berpengaruh positif terhadap hasil belajar matematika siswa melalui task commitment dapat dilihat dari usaha yang dilakukan untuk sukses. Self efficacy akan menentukan seberapa keras usaha yang dilakukan untuk mengatasi persoalan atau menyeleksi tugas dan seberapa lama dia akan mampu berhadapan dengan hambatan yang tidak diinginkan

3. Task Commitment Berpengaruh Langsung terhadap Hasil Belajar Matematika Siswa

Hipotesis ketiga dalam penelitian ini adalah task commitment berpengaruh positif terhadap hasil belajar matematika. Berdasarkan hasil pengujian, maka dapat diketahui bahwa hipotesis ketiga diterima sebab variabel task commitment berpengaruh dengan signifikan terhadap hasil belajar matematika.

Siswa yang memiliki task commitment yang tinggi tidak mudah puas dengan pekerjaaan yang apa adanya, harapan yang tinggi untuk menyelesaikan tugas dengan cepat, tepat waktu serta hasil yang maksimal. Sehingga task commitment juga merupakan motivasi internal dalam diri siswa yang dapat menjadi daya dorong kuat untuk memunculkan potensi yang dimiliki dan memperoleh prestasi yang baik. Hasil penelitian dari Winarti (2006) 
menyimpulkan bahwa siswa yang mempunyai komitmen tinggi pada tugas-tugas belajar memiliki prestasi belajar matematika lebih baik dari siswa yang mempunyai komitmen pada tugas-tugas belajar yang rendah.

Begitu pula dalam pelajaran matematika, bila ia merasa yakin bahwa ia dapat menyelesaikan tugas-tugas matematika dengan baik, maka ia akan menunjukkan usaha dan bekerja lebih keras untuk memecahkan suatu masalah yang dihadapinya. Sebaliknya ia merasa kurang yakin akan keampuan dirinya, maka ia akan mudah menyerah dan tidak berusaha mencari jalan untuk pemecahan masalah.

Nicholls (1972) dan MacKinnon (1960) yang dikutip oleh Hawadi (2002: 69), mengadakan sebuah riset yang berbeda dengan populasi yang beragam namun diperoleh kesimpulan yang sama. Pertama, kemampuan akademis menunjukkan hubungan yang terbatas dengan prestasi kreatif-produktif. Kedua, faktor-faktor non-intelektual, khususnya tanggung jawab terhadap tugas (task commitment) secara konsisten memegang peran penting dalam kluster orang-orang yang kreatif-produktif atau dengan kata lain dalam prestasinya. Dengan demikian secara umum orang yang mempunyai task commitment mempunyai segi-segi mental orang yang kreatif.

Akan tetapi intelegensi, task commitment dan self efficacy tidaklah menjadi faktor utama keberhasilan dalam belajar. Hal ini dapat dilihat pada presentase nilai intelegensi, task commitment, self efficacy dan hasil belajar matematika. Terlihat bahwa intelegensi siswa berada dikategori rata-rata, nilai task commitment berada pada kategori tinggi dan self efficacy juga berada pada kategori tinggi akan tetapi persentase hasil belajarnya berada pada kategori sangat rendah. Hal ini dimungkinkan karena ada beberapa faktor yang mungkin saja mempengaruhi hal tersebut.

Ada beberapa hal yang mungkin mempengaruhi hasil belajar siswa kelas X SMA Negeri di Kecamatan Bulukumpa.

Hal yang mungkin mempengaruhi yaitu yang pertama sikap siswa. sikap merupakan respon awal yang diberikan oleh subjek terhadap objek, barang dan sebagainya. Sikap disini dapat berupa sikap positif dan negatif. Menurut Syah (2011: 132) bahwa sikap siswa yang positif terutama kepada guru dan mata pelajaran merupakan pertanda awal yang baik bagi proses belajar siswa tersebut, sebaliknya sikap negatif siswa terhadap guru dan mata pelajarn tertentu, apalagi jika diiringi dengan kebencian terhadap mata pelajaran dapat menimbulkan kesulitan belajar bagi siswa tersebut. Kedua yaitu fasilitas belajar. Fasilitas belajar merupakan sarana pelengkap bagi siswa untuk mempermudah dalam proses belajarnya yang dapat berupa barang atau perlengkapan lainnya Semakin lengkap fasilitas yang anak peroleh maka kemungkinan keberhasilan anak juga akan semakin tinggi. Hal ini sesuai dengan pendapat Slameto (2003: 66) bahwa "anak yang sedang belajar selain harus terpenuhi kebutuhan pokoknya juga membutuhkan fasilitas belajar seperti ruang belajar, alat tulis menulis buku dan lain-lain". Dan yang ketiga yaitu guru. Untuk mendapatkan hasil belajar yang optimal, banyak dipengaruhi oleh komponen-komponen belajar mengajar. Seorang guru dalam pendidikan memegang peranan yang penting. Guru tidak hanya dituntut untuk memiliki kemampuan dalam pengalaman teoretis tapi juga harus memiliki kemampuan praktis. Selanjutnya dikatakan pula bahwa kualitas dan keberhasilan pembelajaran sangat dipengaruhi oleh kemampuan dan ketetapan guru dalam memilih dan menggunakan metode pembelajaran. Oleh karena itu, guru juga memiliki peeranan penting dalam keberhasilan siswa dalam proses pembelajaran.

\section{SIMPULAN DAN SARAN}

Berdasarkan hasil analisis data penelitian pada bab sebelumnya, beberapa kesimpulan dari hasil penelitian ini adalah:

1. Sebagian besar siswa kelas X SMA Negeri di Kecamatan Bulukumpa Kabupaten Bulukumba, memiliki intelegensi pada kategori average dengan taksiran rata-rata antara $98,40 \leq \mu \leq 101,66$, task commitment dalam belajar matematika pada kategori tinggi dengan taksiran rata-rata antara 73,52 $\leq \mu \leq 77,18$, self efficacy dalam belajar matematika pada kategori tinggi dengan taksiran rata-rata antara $52,96 \leq \mu \leq 55,64$ dan hasil belajar matematika berada pada kategori sangat rendah dengan taksiran rata-rata antara $47,80 \leq \mu \leq 54,10$ 
2. Intelegensi berpengaruh signifikan secara langsung terhadap hasil belajar matematika dengan taraf kepercayaan sebesar $99 \%$.

3. Intelegensi berpengaruh signifikan secara langsung terhadap task commitment dengan taraf kepercayaan sebesar $99 \%$.

4. Self efficacy berpengaruh signifikan secara langsung terhadap hasil belajar matematika dengan taraf kepercayaan sebesar $98 \%$.

5. Self efficacy berpengaruh signifikan secara langsung terhadap task commitment dengan taraf kepercayaan sebesar $99 \%$.

6. Task commitment berpengaruh signifikan terhadap hasil belajar matematika dengan taraf kepercayaan $98 \%$.

7. Intelegensi berpengaruh signifikan terhadap hasil belajar matematika melalui task commitment dengan taraf kepercayaan sebesar 53\%.

8. Self efficacy berpengaruh signifikan terhadap hasil belajar matematika melalui task commitment dengan taraf kepercayaan sebesar 53\%.

Berdasarkan hasil penelitian ini disarankan

1. Kepada para guru yang bersangkutan sebaiknya memperhatikan faktor-faktor psikologis siswa diantaranya intelegensi, self efficacy dan task commitment pada saat proses belajar dan mengajar matematika sehingga dapat berimplikasi pada peningkatan hasil belajarnya terutama pada saat belajar matematika. Selain itu diharapkan guru dapat menciptakan suasana kelas yang aktif dan menyenangkan agar siswa tertarik dengan matematika

2. Kepada peneliti yang berminat meneliti, agar meneliti sumbangan efektif intelegensi, self efficacy dan task commitment secara lebih mendalam serta variabel lain yang dapat memprediksi hasil belajar matematika siswa, misalnya: bakat, kesiapan belajar siswa dan kompetensi guru.

3. Kepada praktisi pendidikan, dalam menerapkan pengembangan aspek intelegensi, self efficacy dan task commitment pada siswa diharapkan melakukannya dalam bentuk pelatihan sehingga pengaruh yang didapatkan siswa lebih konkrit.

\section{DAFTAR PUSTAKA}

Azwar. 2013. Pengantar Psikologi Intelegensi. Yogyakarta: Pustaka Pelajar.
Firmanto, A. 2013. Kecerdasan, Kreatiftas, Task Commitment dan Jenis Kelamin Sebagai Prediktor Prestasi Hasil Belajar Siswa. Jurnal Sains dan Praktik Psikologi Magister Psikologi Universitas Muhammadiyah Malang, ISSN: 23032936, I (1), 26 - 36.

Ghufron, M. N \& Risnawita, R. 2010. TeoriTeori Psikologi. Jogyakarta: Ar-Ruzz Media Group.

Hadis, A \& Nurhayati. 2014. Psikologi dalam Pendidikan. Bandung: Alfabeta.

Hawadi, R, A. 2002. Identifikasi Keberbakatan Intelektual Melalui Metode Non-Tes. Jakarta: Grasindo.

Harahap, D. 2011. Analisis Hubungan antara Efikasi-Diri Siswa dengan Hasil Belajar Kimia. Jurnal Pendidikan Kimia UNIMED. Vol (5), (42-53).

Jainuri, M. 2009. Pengaruh Sikap dan Tingkat Intelegensi terhadap Prestasi Belajar Matematika Siswa Kelas XI SMK Tri Bhakti Bangko Tahun Ajaran 2009/2010 (Online), http://www.academia.edu/4613087/Jur nal. Diakses 8 Juli 2015

Kunandar.2008. Langkah Mudah Penelitian Tindakan Kelas Sebagai Pengembangan Profesi Guru. Jakarta: Rajawali Press.

Muammar, O, M. 2011. Intelligence and SelfControl Predict Academic Performance of Gifted and Non-gifted Students. AsiaPacific Journal of Gifted and Talented Education, 3 (1), 18-32.

Ormrod, J,E. 2009. Psikologi Pendidikan Jilid 2: Membantu Siswa Tumbuh dan Berkembang.Jakarta: Erlangga.

Sardiman. A. M. 2011. Interaksi dan Motivasi Belajar Mengajar. Jakarta: Rajawali Pers.

Setyaningsih, A, D. 2009. Komitmen Pada Tugas (Task Commitment) Siswa Smp Ditinjau Dari Persepsi Terhadap Peran Sebagai Siswa. Tesis. Unika.

Slameto. 2003. Belajar dan Faktor-Faktor yang Mempengaruhinya. Edisi Revisi. Cet: keempat. Jakarta: Rineka Cipta.

Sudiarta, Marhaeni \& Suhandana. 2013. Kontribusi Tingkat Intelegensi, Nilai Ujian Nasional Bahasa Inggris SMP, Minat Belajar Bahasa Inggris terhadap Prestasi Belajar Bahasa Inggris Siswa 
Kelas X Sma Negeri 2 Amlapura Tahun Pelajaran 2012/2013. e-Journal Program Pascasarjana Universitas Pendidikan Ganesha, vol. 4.

Suryabrata, S. 2014. Psikologi Pendidikan. Jakarta: Rajawali Press.

Syah. 2011. Psikologi Pendidikan dengan

Pendekatan Baru. Edisi Revisi,

Bandung: PT Remaja Rosdakarya.

Syarifa, A, D. Mustami'ah \& W. Sulistiani. 2011. Hubungan antara Dukungan Sosial Orang Tua dengan Komitmen Terhadap Tugas (Task Commitment) pada Siswa Akselerasi Tingkat SMA. INSAN. Fakultas Psikologi, Universitas Hang Tuah Surabaya, 13 (01).

Tiro, M. A. \& Arbianingsih. 2011. Teknik Pengambilan Sampel. Makassar: Andira Publisher.

Tiro, M. A \& Sukarna. 2012. Pengembangan Instrumen Pengumpulan Data Penelitian. Makassar: Andira Publisher.

Winarti, A. 2006. Pengaruh Kemampuan Intelegensi dan Task Commitment Terhadap Prestasi Belajar Matematika Siswa Kelas II SLTPN 1 Gemolong. Skripsi Universitas Sebelas Maret Surakarta. 